BMC

Veterinary Research

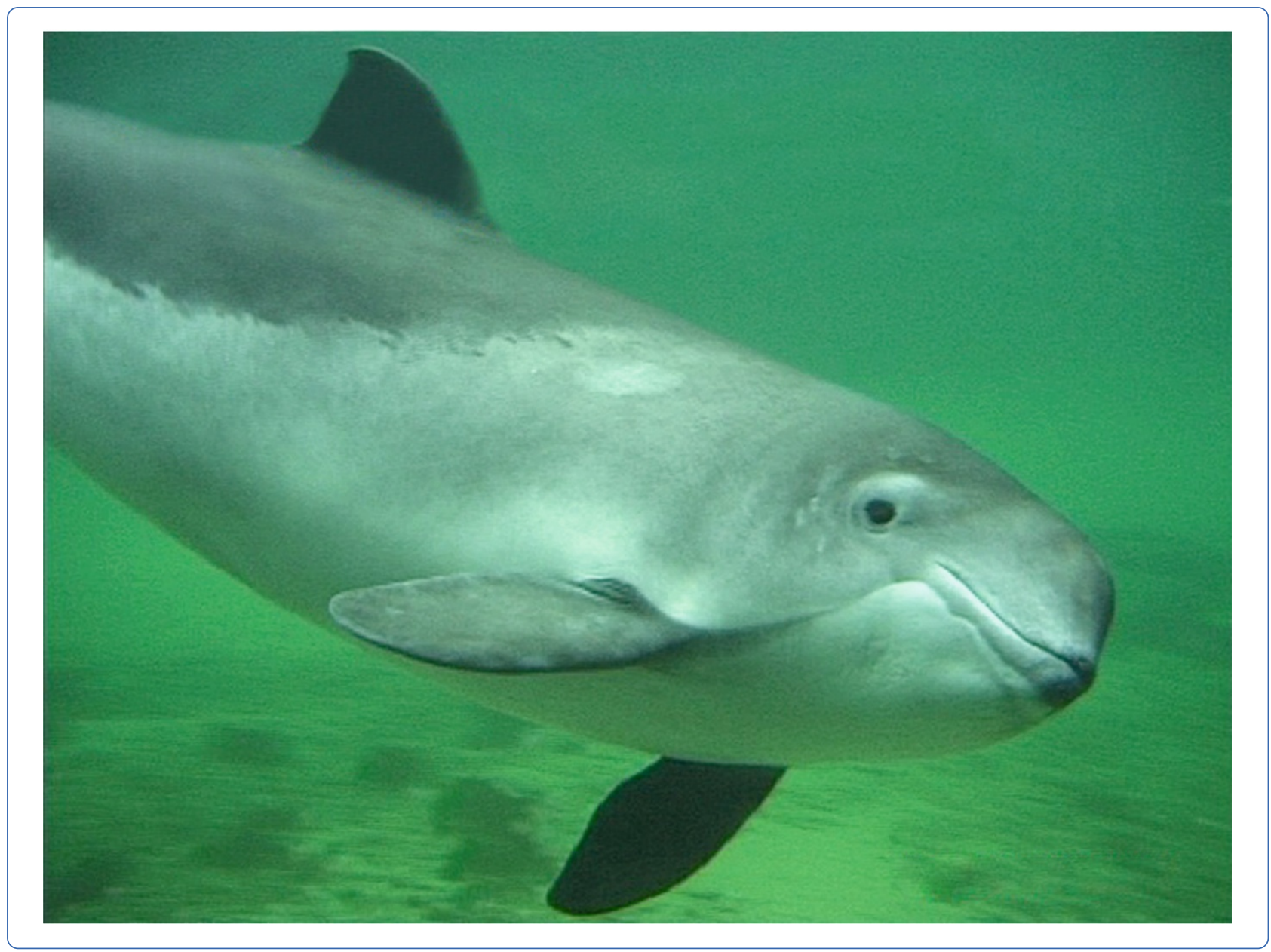

Evaluation of immune and stress status in harbour porpoises (Phocoena phocoena): can hormones and mRNA expression levels serve as indicators to assess stress?

Müller et al. 


\title{
Evaluation of immune and stress status in harbour porpoises (Phocoena phocoena): can hormones and mRNA expression levels serve as indicators to assess stress?
}

Sabine Müller ${ }^{1}$, Kristina Lehnert ${ }^{1,2}$, Henrike Seibel ${ }^{1}$, Jörg Driver ${ }^{3}$, Katrin Ronnenberg ${ }^{1}$, Jonas Teilmann ${ }^{4}$, Cornelius van Elk ${ }^{5}$, Jakob Kristensen ${ }^{6}$, Eligius Everaarts ${ }^{7}$ and Ursula Siebert ${ }^{{ }^{*}}$

\begin{abstract}
Background: The harbour porpoise is exposed to increasing pressure caused by anthropogenic activities in its marine environment. Numerous offshore wind farms are planned or under construction in the North and Baltic Seas, which will increase underwater noise during both construction and operation. A better understanding of how anthropogenic impacts affect the behaviour, health, endocrinology, immunology and physiology of the animals is thus needed. The present study compares levels of stress hormones and mRNA expression of cytokines and acute-phase proteins in blood samples of harbour porpoises exposed to different levels of stress during handling, in rehabilitation or permanent human care.

Free-ranging harbour porpoises, incidentally caught in pound nets in Denmark, were compared to harbour porpoises in rehabilitation at SOS Dolfijn in Harderwijk, the Netherlands, and individuals permanently kept in human care in the Dolfinarium Harderwijk and Fjord \& Belt Kerteminde, Denmark. Blood samples were investigated for catecholamines, adrenaline, noradrenaline and dopamine, as well as for adrenocorticotropic hormone (ACTH), cortisol, metanephrine and normetanephrine. mRNA expression levels of relevant cell mediators (cytokines IL-10 and TNFa, acute-phase proteins haptoglobin and C-reactive protein and the heat shock protein HSP70) were measured using real-time PCR.

Results: Biomarker expression levels varied between free-ranging animals and porpoises in human care. Hormone and cytokine ranges showed correlations to each other and to the health status of investigated harbour porpoises. Hormone concentrations were higher in free-ranging harbour porpoises than in animals in human care. Adrenaline can be used as a parameter for the initial reaction to acute stress situations; noradrenaline, dopamine, ACTH and cortisol are more likely indicators for the following minutes of acute stress. There is evidence for different correlations between production of normetanephrine, metanephrine, cortisol and the expression of IL-10, HSP70 and haptoglobin.
\end{abstract}

Conclusions: The expression patterns of the selected molecular biomarkers of the immune system are promising to reflect the health and immune status of the harbour porpoise under different levels of stress.

Keywords: Harbour porpoise, Stress hormones, Cytokines, Anthropogenic impact, Offshore wind farms, Underwater noise

\footnotetext{
* Correspondence: Ursula.Siebert@tiho-hannover.de

${ }^{1}$ Institute for Terrestrial and Aquatic Wildlife Research, University of Veterinary

Medicine Hannover, Foundation, Büsum 25761, Germany

Full list of author information is available at the end of the article
} 


\section{Background}

The harbour porpoise (Phocoena phocoena) is the only reproducing cetacean species in the Baltic Sea and eastern North Sea [1-3]. These waters are highly exposed to anthropogenic impacts as an increasing number of human activities are conducted in these areas, including shipping, construction of offshore wind farms, fisheries, seismic and military operations. These activities cause underwater noise which results in disturbance of and stress in the marine fauna [3-9].

High-intensity underwater noise can cause permanent or temporary threshold shifts in the auditory system and, apart from being responsible for masking and behavioural changes, it is supposed to cause an increased level of stress for the animals $[4,10]$. Stress is often defined as the body's reaction to a change that requires a physical, mental or emotional adjustment or response. Although stress occurs naturally in wildlife due to e.g. social competition, breeding behaviour or environmental demands, anthropogenic impacts such as vessel traffic, noise, fishing and chemical pollution can impose significant additional stress [10-12]. Capture and handling are critical stress factors especially for wild marine mammals but also for those temporarily or permanently in human care [13-16]. Periods of stress cause endocrinological, immunological and physiological reactions that can result in immune suppression and deleterious health effects if stressors are chronic $[11,17,18]$. Catecholamines are associated with a fast "fight-or-flight" reaction as their levels increase rapidly in response to stressors [11,19]. Cortisol is an endogenous glucocorticoid produced in the adrenal cortex under control of adrenocorticotropic hormone $(\mathrm{ACTH})$, produced in the pituitary gland which, in turn, is controlled by the hypothalamus (corticotropin-releasing hormone, $\mathrm{CRH}$ ). It has a broad spectrum of metabolic and immunemediating effects mainly associated with stress reactions $[11,20,21]$.

Stress-induced changes to the immune system can increase the risk of infections, neoplasia and immunemediated disorders [11,22,23]. We chose biomarkers for the detection of pathological immune responses in order to determine the impact of anthropogenic stressors on the health status of free-ranging porpoises and individuals in human care. Acute-phase proteins serve diverse physiological functions of the immune system and are used as markers to detect infection and stress [24-26]. The acute-phase protein HSP70 has been reported to be a cell mediator reacting to bacterial, viral and parasitic pathogens $[27,28]$. Cytokines and acute-phase proteins as immune mediators have been used to assess the health status and immune system in cetaceans and pinnipeds [29-37].

The aim of this study was to measure stress hormones and cell mediators of the stress-related immune response in the blood of harbour porpoises to determine anthropogenically caused stress. Catecholamines (adrenaline, noradrenaline, dopamine) and their degradation products metanephrine and normetanephrine, cortisol, adrenocorticotropic hormone $(\mathrm{ACTH})$, and messenger-Ribonucleic acid (mRNA) expression levels of selected cell mediators responsible for the immune response heat shock protein (HSP70), acute-phase proteins (APP) haptoglobin (HP), C-reactive protein (CRP) and cytokines Interleukin 10 (IL10) and Tumor Necrosis Factor (TNF $\alpha)$ were studied.

\section{Methods}

\section{Harbour porpoise sampling}

For the present study 28 live porpoises were sampled. Those animals can be divided into three different groups:

(1) Free-ranging animals (number $(n)=7$ ), by-caught in pound-nets by Danish fishermen, were sampled during field trials including tagging and recording of audiograms of the animals.

(2) Porpoises sampled at the Dolfinarium Harderwijk, the Netherlands, $(n=8)$ and at the Fjord and Baelt Kerteminde, Denmark, $(n=1)$ are kept permanently in human care (1-13 years). These animals are trained for medical purposes to allow voluntary handling and sampling but were taken out of the pool for blood sampling in this study.

(3) Porpoises in rehabilitation $(n=12)$ at the rehabilitation centre SOS Dolfijn in Harderwijk were found stranded and are in human care only temporarily (3-6 months). During their stay in the rehabilitation centre these animals are getting accustomed to human handling. They were sampled over several weeks at varying frequency depending on the duration of their rehabilitation and on their health status.

\section{Blood sampling}

Blood samples were obtained from the veins of the fluke using the method described by [12]. Handling and sampling of the free-ranging porpoises were carried out directly on board the fishermen's boats after the harbour porpoises had been lifted out of the pound nets [12], experimental research on the study animals followed internationally recognized guidelines and was approved by an appropriate ethics commttee with permits from the Danish Forest and Nature Agency SN 343/SN-0008 and Ministry of Justice 1995-101-62]. Three samples were taken: the first directly when the animal was taken out of the pound net, the second two and the last 3.5 hours later.

Sampling of the animals in permanent human care and in rehabilitation was performed during routine medical investigations in the facilities. Sampling was conducted directly after the animals were taken out of 
the water. The broad spectrum of parameters to be analysed required fairly large sample volumes of about $10 \mathrm{ml}$, but it was not always possible to obtain a sufficient amount of blood. Due to this limitation not every animal was investigated for the full hormone and biomarker profiles.

\section{Differential haematology and serum chemistry}

For differential haematology and serum chemistry, venous whole blood was collected in tubes with ethylenediaminetetraacetic acid (EDTA) anticoagulant and tubes with coagulation gel for serum extraction. Differential haemogram profiles were generated with a ScilVet $\mathrm{ABC}^{\mathrm{Tm}}$ Animal Blood Counter (Scil Animal Care Company GmbH, 68519 Viernheim, Germany). Serum separator tubes were centrifuged for 15 minutes after blood was clotted (Hettich ${ }^{\text {тм }}$ EBA I centrifuge, Andreas Hettich GmbH \& Co. KG, 78532 Tuttlingen, Germany). Serum was extracted, frozen at $-20^{\circ} \mathrm{C}$ and later sent to the veterinary laboratory Synlab Vet in Geesthacht, Germany, for determination of blood chemistry parameters.

\section{Hormone analysis}

Blood was collected in tubes with EDTA, ethyleneglycoltetraacetic acid (EGTA) anticoagulant and tubes with coagulation gel for serum extraction, cooled until centrifugation at $2500 \mathrm{U} / \mathrm{min}$ for $15 \mathrm{mi}$ nutes, and frozen at $-20^{\circ} \mathrm{C}$ in $1 \mathrm{ml}$ aliquots. Serum, EGTA plasma and EDTA plasma hormone levels were measured following standard techniques in a commercial laboratory (Endokrinologikum, Hamburg, Germany). For the quantitative analysis of the catecholamines adrenaline (41 samples, Firma Recipe Chemicals + Instruments $\mathrm{GmbH}$ München, IntraAssay: CV 7.6\%, Inter-Assay: 4.2\%), noradrenaline (41 samples, Firma Recipe Chemicals + Instruments GmbH München, Intra-Assay: CV 6.7\%, Inter-Assay: 5.3\%) and dopamine (41 samples, Firma Recipe Chemicals + Instruments GmbH München, Intra-Assay: CV 6.1\%, Inter-Assay: 3.9\%) a high-performance liquid chromatography (HPLC) was performed. Cortisol levels (46 samples) were estimated via a competitive electrochemiluminescent immunoassay (ECLIA, Cobas sheep-antibody, Intra-Assay: CV 1.5-1.6\%, Inter-Assay: 1.1-1.3\%), levels of ACTH (32 samples, CLIA chemiluminescent immunoassay, DiaSorin, monoclonal mouseantibody, Intra-Assay: CV 2.6-4.9\%, Inter-Assay: 5.5-8.9\%) by a non-competitive electrochemiluminescent immunoassay. Metanephrine (25 samples, Labor Diagnostic Nord GmbH \& Co. KG Nordhorn, LDN, rabbit antiserum, Intra-Assay: CV 8.7-15\%, Inter-Assay: 11-14\%) and normetanephrine (25 samples, Labor Diagnostic Nord GmbH \& Co. KG Nordhorn, LDN, rabbit antiserum,
Intra-Assay: CV 7.9-10\%, Inter-Assay: 5.6-8.3\%) contents were estimated using a radioimmunoassay.

\section{Real-time PCR analysis}

Blood samples were taken in EDTA monovettes containing $3 \mathrm{ml}$ of RNAlater and ice cooled until arrival at the lab where RNA was isolated. Total RNA was isolated from $500 \mu \mathrm{L}$ EDTA blood (RiboPure ${ }^{\mathrm{TM}}$ Blood Kit, Ambion Europe, Huntington, UK) according to the manufacturer's protocol.

Published primers were used for the housekeeping gene Glyceraldehyde 3-phosphate dehydrogenase (GAPDH) [29], the cytokines IL-10 and TNFo [32] and the APPs CRP and Haptoglobin (HP) [33] and HSP70 [34]. Primers for the housekeeping gene 14-3-3 protein zeta/delta (YWHAZ) were designed and established by [38]. 80-100 ng/ $\mu \mathrm{L}$ RNA was reverse transcribed with murine reverse transcriptase (Real time-Polymerase chain reaction (RT-PCR) Core $\mathrm{Kit}^{\mathrm{T \mu}}$; Applied Biosystems, Weiterstadt, Germany). The resulting cDNA served as a template for real-time PCR using the Thermocycler MX4000 ${ }^{\text {TM }}$ Real-Time PCR Systems (Stratagene Europe, Amsterdam, Netherlands). For real-time quantification the Brilliant III Ultra-Fast SYBR ${ }^{\odot}$ Green QPCR Master Mix (Agilent Technologies) was used, containing SYBR Green I as a fluorescence dye, dNTP's, $\mathrm{MgCl}_{2}$ and a hot start Taq DNA polymerase. For each parameter a standard curve was prepared using a dilution series from $10 \mathrm{e} 8$ to $10 \mathrm{e} 2$ copies. The polymerase chain reaction (PCR) started with an initial step at $95^{\circ} \mathrm{C}$ for $3 \mathrm{~min}$, followed by 45 cycles with denaturation at $95^{\circ} \mathrm{C}$ for $5 \mathrm{sec}$ and a primer-specific annealing temperature for $20 \mathrm{sec}$. The annealing temperatures are shown in Table 1. Fluorescence was measured at the end of the annealing and at the end of the dissociation program at a wavelength of $530 \mathrm{~nm}$. To exclude measurement of nonspecific PCR products and primer dimers, and to determine true amplification, each PCR was followed by a dissociation program for $1 \mathrm{~min}$ at $95^{\circ} \mathrm{C}$, followed by 41 cycles during which the temperature was increased in each cycle, starting at $55^{\circ} \mathrm{C}$ and ending at $95^{\circ} \mathrm{C}$. Only PCR reactions with one well-defined peak were used for analysis. All reactions were performed in duplicate. The constitutively expressed housekeeping genes GAPDH and YWHAZ were used as control genes and to normalise cytokine and APP expression. geNorm software (version 3.5; March 2007) was used to test stability of the candidate reference genes [39].

\section{Statistical analysis}

Statistical evaluations were performed with the free statistics software $R[R$ version 2.15.2, [40]]. Linear mixed models (LMM) were applied throughout on log-transformed data using the package "nlme" [41]. 
Table 1 Primer-specific sequences, annealing temperatures and base pair length for housekeeping genes, cytokines, acute-phase proteins and heat shock protein

\begin{tabular}{|c|c|c|c|c|}
\hline Cellmediators/mol. biomarkers & & Primer sequences $\left(5^{\prime}-3^{\prime}\right)$ & Annealing temperature & Base pair length \\
\hline \multirow[t]{2}{*}{ YWHAZ } & $\mathrm{s}$ & AGA CGG AAG GTG CTG AGA AA & $58^{\circ} \mathrm{C}$ & 208 \\
\hline & AS & TCA TVA CCA GCA GCA ACT TC & & \\
\hline \multirow[t]{2}{*}{ GAPDH } & $\mathrm{s}$ & GCC AAA AGG GTC ATC ATC TC & $57^{\circ} \mathrm{C}$ & 201 \\
\hline & AS & GGG GCC ATC CAC AGT CTT CT & & \\
\hline \multirow[t]{2}{*}{ IL-10 } & $\mathrm{s}$ & CCT GGG TTG CCA AGC CCT GTC & $62^{\circ} \mathrm{C}$ & 208 \\
\hline & AS & ATG CGC TCT TCA CCT GCT CC & & \\
\hline \multirow[t]{2}{*}{ TNFa } & $\mathrm{s}$ & GGC TGA ACA CAT ATG CCA AC & $57^{\circ} \mathrm{C}$ & 111 \\
\hline & AS & TGA AGA GGA CCT GGG AGT AGA & & \\
\hline \multirow[t]{2}{*}{ HP } & S & CTG GCA GGC TAA GAT GGT TT & $54^{\circ} \mathrm{C}$ & 75 \\
\hline & AS & GTC AGC AGC CAT TGT TCA TT & & \\
\hline \multirow[t]{2}{*}{ CRP } & S & TTC TCG TAT GCC ACC AAG AG & $54^{\circ} \mathrm{C}$ & 192 \\
\hline & AS & TTC AGA CCC ACC CAC TGT AA & & \\
\hline \multirow[t]{2}{*}{ HSP 70} & S & GGG GCT GAA CGT GCT GAG G & $62^{\circ} \mathrm{C}$ & 280 \\
\hline & AS & CCG CTT GTT CTG GCT GAT GTC & & \\
\hline
\end{tabular}

For comparisons between the three groups, animals in human care, in rehabilitation and free-ranging, sampling (repeated measures) was included as random slope term, where possible, and the "Porpoise ID" (the identification number of individual porpoises) as random intercept to avoid pseudo-replication. For some hormones and biomarkers (normetanephrine, ACTH, Cortisol, CRP, HP, $\mathrm{TNF} \alpha$ ), we included sampling as nested factor in the identification (ID) term because of numerical problems due to fewer measurements per animal. We included the group (free-ranging, rehabilitation and human care) and a sex factor as fixed effects. We achieved minimal adequate models of fixed effects by backward selection based on the lowest AIC (Akaikes Information Criterion) values using maximum likelihood estimation. To allow for variance heterogeneity, a variance-by-group structure was included if diagnostic plots and AIC values indicated violation of the residual homogeneity assumption (CRP and TNF $\alpha$ ). To test the effect of time for animals in rehabilitation, we chose the first and last received blood sample of those porpoises and compared them to free-ranging animals and animals in human care. The porpoise ID was included as random intercept term. To test relations between hormones and biomarkers we conducted Spearman rank correlations between all hormones and biomarkers. Only relations with a correlation coefficient rho $>0.4$ are presented.

\section{Results}

Differential haematology and serum chemistry

Differential haematology was conducted for seven freeranging animals, one of them was sampled once, four were sampled twice and two were sampled three times.
The number of leukocytes varied between 3,600 and 9,000 cells per cubic millimetre of blood. In comparison to previous levels one animal showed an elevated level of leukocytes indicating an infection. With the exception of one animal, leukocyte levels decreased between 3-11\% in animals if measured three times in the same animal around the time an audiogram was measured. No animal showed indications of a stress leukogram compared to reference values (elevated neutrophils in combination with eosinopenia, lymphopenia and occasionally monocytosis; [42]). One animal had a decreased number of erythrocytes (2,836-2,916 cells per cubic millimetre of blood) and also decreased haemoglobin, haematocrit and iron levels $4.3 \mu \mathrm{mol} / \mathrm{l} ;$ [42]. The number of platelets and the differential were all within normal range [42]. Blood chemistry revealed that only two investigated individuals showed increased liver enzymes alkaline phosphatase (ALP) from 424 to $471 \mathrm{U} / \mathrm{L}$ and glutamic pyruvic transaminase (GPT) from 109 to $143 \mathrm{U} / \mathrm{L}$ compared to reference values of harbour porpoises in human care and from the wild [42].

\section{Hormone analysis}

A summary of the median hormone levels is presented in Table 2.

\section{Adrenaline}

Median adrenaline levels were significantly higher in free-ranging porpoises than in porpoises in permanent human care (linear mixed model, $\mathrm{p}=0.02$ ). Porpoises in rehabilitation showed non-significant, intermediate adrenaline levels $(\mathrm{p}>0.1)$ in comparison to free-ranging animals and animals in human care (Figure 1a). Porpoises in human care ( 9 animals, 11 samples) showed 
Table 2 Median and first to third quartile of all hormone levels for free-ranging porpoises, porpoises in rehabilitation and in human care (unit for cortisol: $\mathbf{n g} / \mathrm{ml}$; for all other hormones: $\mathbf{n g} / \mathrm{l}$ )

\begin{tabular}{|c|c|c|c|c|c|c|c|c|c|}
\hline & \multicolumn{3}{|c|}{ Free-ranging } & \multicolumn{3}{|c|}{ Rehabilitation } & \multicolumn{3}{|c|}{ Human care } \\
\hline & $\mathrm{n}$ & median & 1. - 3. quartile & $\mathrm{n}$ & median & 1. - 3. quartile & $\bar{n}$ & median & 1. - 3. quartile \\
\hline adrenaline & 15 & 189 & $126.5-280.5$ & 15 & 100 & $82.15-142$ & 11 & 86.2 & $58.85-103.24$ \\
\hline noradrenaline & 15 & 3068 & $1970.5-4372$ & 15 & 1158 & $993-3040$ & 11 & 859.25 & $581.5-1837.5$ \\
\hline dopamine & 15 & 294 & $180.5-448.5$ & 15 & 61 & $38.1-465$ & 11 & 180 & $150.5-262.7$ \\
\hline metanephrine & 9 & 486.6 & 439.3-589 & 14 & 193 & $109-285.5$ & 2 & 90 & $82-98$ \\
\hline normetanephrine & 9 & 938.4 & $676-1107$ & 14 & 499,5 & $482.5-611$ & 2 & 370.5 & $370.5-422$ \\
\hline ACTH & 14 & 283.1 & $119.8-449.8$ & 9 & 29,2 & $20.4-38.4$ & 9 & 40.4 & $39.5-58.3$ \\
\hline cortisol & 14 & 173.7 & $120.9-231.4$ & 17 & 40 & $27.6-59.9$ & 15 & 24.3 & $21.25-31.5$ \\
\hline
\end{tabular}

$\mathrm{n}=$ number of samples.

adrenaline concentrations between 34.2 and $241 \mathrm{ng} / \mathrm{l}$ with a median of $86.2 \mathrm{ng} / \mathrm{l}$. Porpoises in rehabilitation (8 animals, 15 samples) ranged between 46 and $612 \mathrm{ng} / \mathrm{l}$. The median of all values was $100 \mathrm{ng} / \mathrm{l}$. In free-ranging porpoises ( 7 animals, 15 samples) concentrations ranged between 30.5 and $455 \mathrm{ng} / \mathrm{l}$ with a median of $189 \mathrm{ng} / \mathrm{l}$.

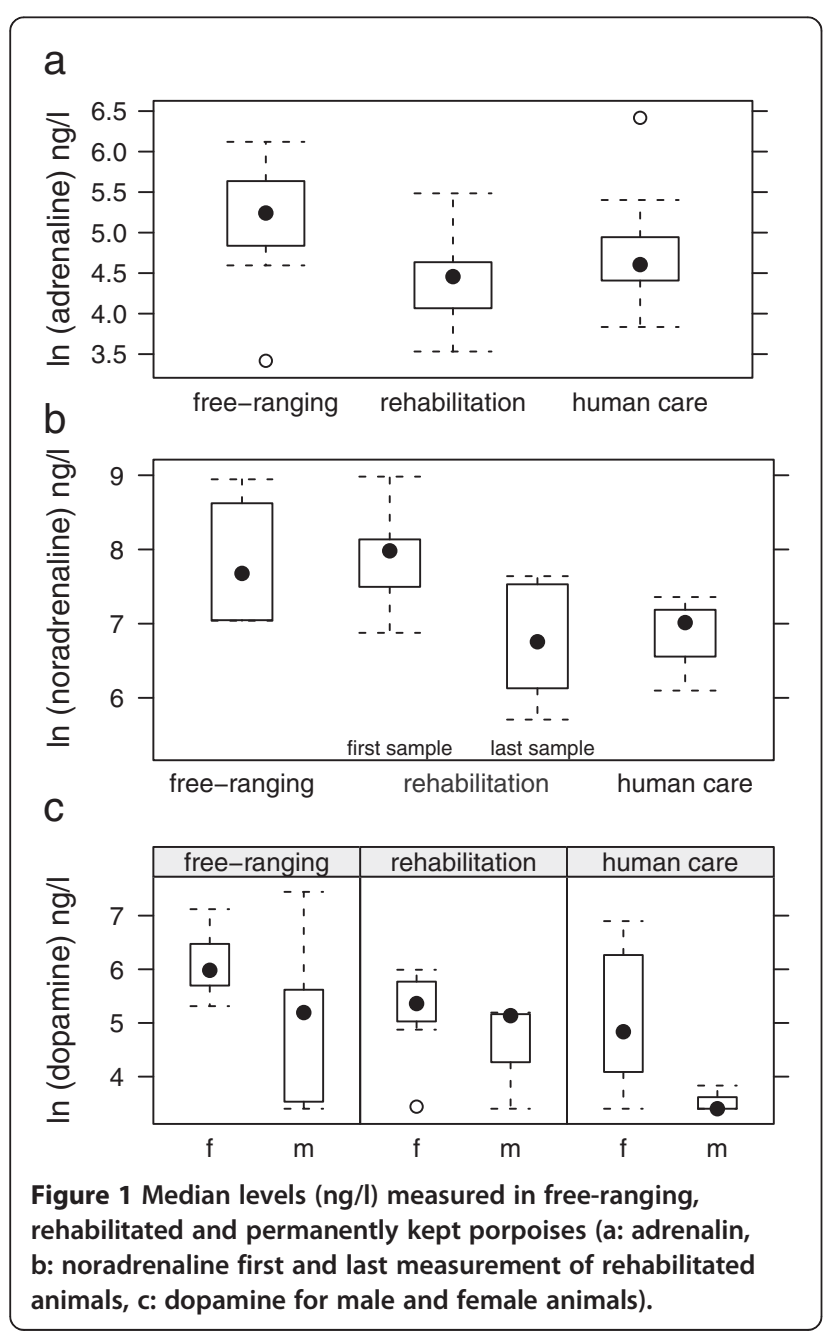

\section{Noradrenaline}

Median levels of noradrenaline were significantly higher in free-ranging porpoises $(\mathrm{p}=0.0013)$ and animals in rehabilitation $(\mathrm{p}=0.04)$ when compared to animals in permanent human care using a global comparison with linear mixed models. Porpoises in human care (9 animals, 11 samples) showed noradrenaline concentrations between 301 and $2080 \mathrm{ng} / \mathrm{l}$, the median was $859.3 \mathrm{ng} / \mathrm{l}$.

Noradrenaline values of porpoises in rehabilitation (8 animals, 15 samples) were between 207 and 7,672 ng/l. The median of all values was $1,158 \mathrm{ng} / \mathrm{l}$. The medians of the first and last measurements were 2,591 and $1,112.5 \mathrm{ng} / \mathrm{l}$, respectively. In free-ranging porpoises (7 animals, 15 samples) noradrenaline concentrations of 969$7,954 \mathrm{ng} / \mathrm{l}$ were measured, the median was 3,068 $\mathrm{ng} / \mathrm{l}$. When splitting the data of the rehabilitated porpoises in two groups by separating the first measurement after arrival in the facility from the last one obtained before release, the first measurement clearly is close to the range of the one found in free-ranging porpoises, while the last one is significantly lower $(p=0.0112)$ than average measurements from free-ranging individuals (Figure 1b).

\section{Dopamine}

Dopamine levels did not differ between groups, but females from all groups showed significantly higher values $(\mathrm{p}=0.0331)$ than males (Figure 1c). Porpoises in human care (9 animals, 11 samples) showed dopamine concentrations between 31.2 and $432.8 \mathrm{ng} / \mathrm{l}$, the median was $180 \mathrm{ng} / \mathrm{l}$.

Porpoises in rehabilitation (8 animals, 15 samples) showed values between $<30$ and $990 \mathrm{ng} / \mathrm{l}$. In 5 of 24 investigated samples dopamine concentration was below the detection limit of $30 \mathrm{ng} / \mathrm{l}$. Dopamine decreased with the length of time animals spent in rehabilitation. In free-ranging porpoises (7 animals, 15 samples) dopamine concentrations of $<30-1,708 \mathrm{ng} / \mathrm{l}$ were measured, the median was $294 \mathrm{ng} / \mathrm{l}$. 


\section{Metanephrine}

Metanephrine values were significantly higher in freeranging porpoises compared to animals in human care $(\mathrm{p}=0.0176)$ according to global comparison with linear mixed models (Figure 2a). Values of porpoises in rehabilitation ranged between the two groups. Only samples from two porpoises in human care were analysed, the median was $90 \mathrm{ng} / \mathrm{l}$.

Metanephrine values of porpoises in rehabilitation (5 animals, 14 samples) ranged between 75.4 and $855 \mathrm{ng} / \mathrm{l}$, the median was $193 \mathrm{ng} / \mathrm{l}$. In free-ranging animals (4 animals, 9 samples) metanephrine concentrations between 157 and 2,272 ng/l were measured, the median was $486.6 \mathrm{ng} / \mathrm{l}$.

\section{Normetanephrine}

Normetanephrine values were significantly higher ( $\mathrm{p}=$ 0.0124 ) in free-ranging porpoises than in those in human care (Figure 2b). Values of porpoises in rehabilitation ranged between the two groups. Normetanephrine levels were significantly higher in male porpoises $(\mathrm{p}=$ 0.038) throughout all groups.

Two samples from porpoises in human care were analysed, their median was $370.5 \mathrm{ng} / \mathrm{l}$. Normetanephrine values of porpoises in rehabilitation (5 animals, 14 samples) were between 128 and 1,079 ng/l with a median of $499.5 \mathrm{ng} / \mathrm{l}$. In free-ranging animals (4 animals, 9 samples) normetanephrine concentrations between 489 and $1,726 \mathrm{ng} / \mathrm{l}$ were found, the median was $938.4 \mathrm{ng} / \mathrm{l}$.

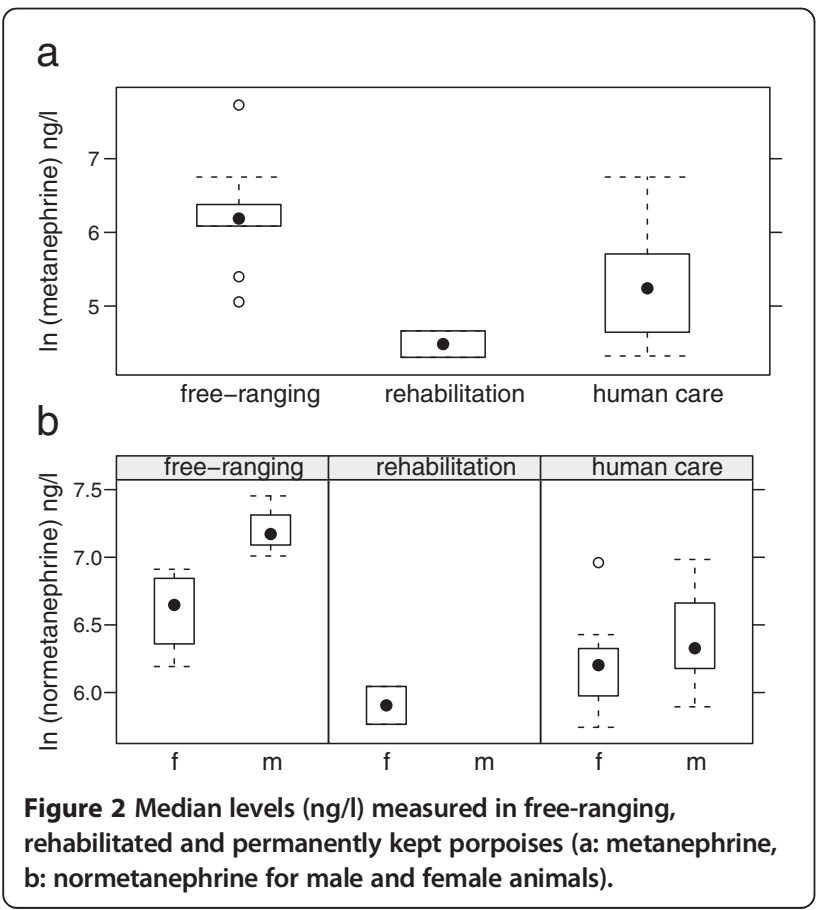

ACTH

$\mathrm{ACTH}$ measurements in porpoises in rehabilitation and human care were significantly lower than those found in free-ranging individuals $(\mathrm{p}=0.001$; Figure $3 \mathrm{a})$. Porpoises in human care ( 9 animals, 9 samples) showed concentrations between 26.8 and $82.1 \mathrm{ng} / \mathrm{l}$, the median was $40.4 \mathrm{ng} / \mathrm{l}$. ACTH values of porpoises in rehabilitation (5 animals, 9 samples) were between 11.2 and $191.8 \mathrm{ng} / \mathrm{l}$, the median was $29.2 \mathrm{ng} / \mathrm{l}$. In free-ranging porpoises (7 animals, 14 samples) ACTH concentrations between 42.3and $998.5 \mathrm{ng} / \mathrm{l}$ were measured, the median was $283.1 \mathrm{ng} / \mathrm{l}$.

\section{Cortisol}

Cortisol levels in porpoises in rehabilitation and human care were significantly lower than in free-ranging individuals ( $p>0.001$; Figure $3 \mathrm{~b}$ ). In porpoises in human care (9 animals, 15 samples) cortisol concentrations ranged between 6.9 and $54.9 \mathrm{ng} / \mathrm{ml}$, the median was $24.3 \mathrm{ng} / \mathrm{ml}$. Cortisol values of porpoises in rehabilitation (7 animals, 17 samples) ranged between 12.7 and $539 \mathrm{ng} / \mathrm{ml}$, the median was $40 \mathrm{ng} / \mathrm{ml}$. Free-ranging porpoises (7 animals, 14 samples) showed cortisol concentrations between 43.7 and $307.8 \mathrm{ng} / \mathrm{ml}$, the median was $173.7 \mathrm{ng} / \mathrm{ml}$.

When separating the group of rehabilitated porpoises and comparing the first measurement after arrival in the

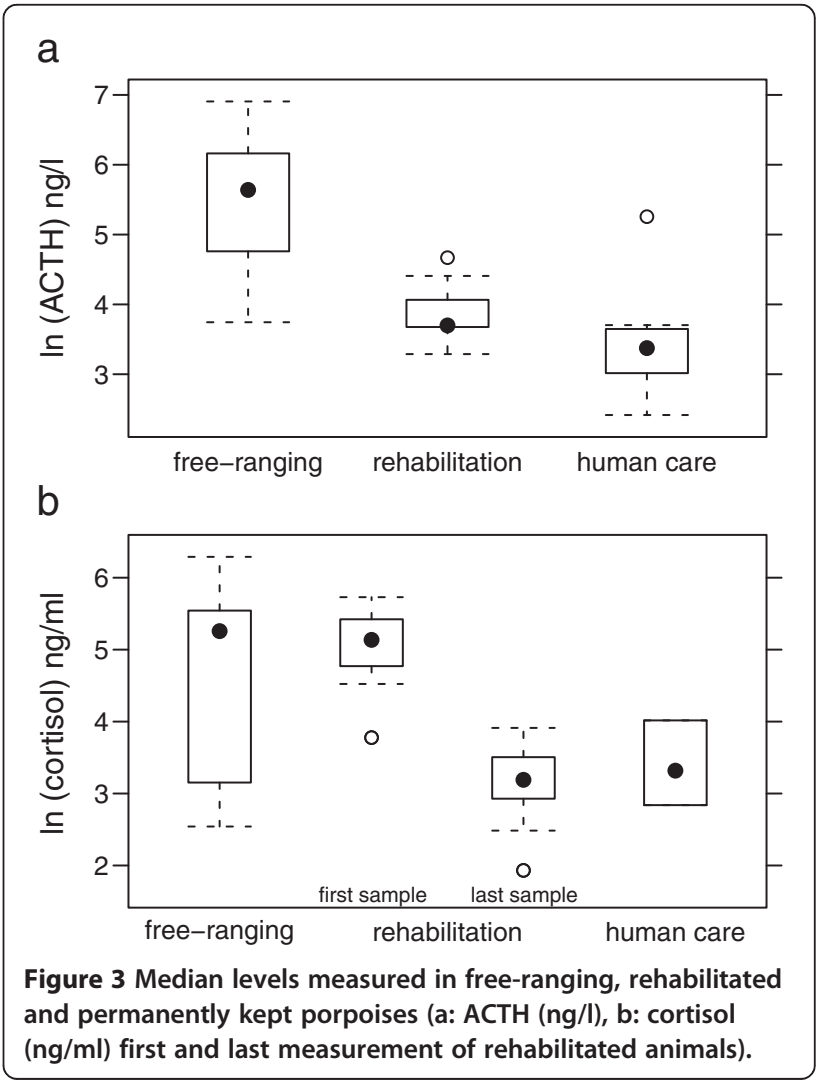


facility with the last one obtained before release, marginally significant differences $(\mathrm{p}=0.052)$ appear between the first value close to the range of the free-ranging animals and the last value similar to the range found in animals in human care (Figure 3b).

\section{$R T-P C R$ analyses}

A summary of the median mRNA expression levels is presented in Table 3.

\section{Acute-phase proteins}

HSP70

mRNA expression levels of HSP70 were significantly higher in male porpoises throughout the groups ( $\mathrm{p}=$ 0.014; Figure 4a), and porpoises in rehabilitation showed lower values than animals in human care. The first sample taken during the rehabilitation process showed significantly lower ranges than those observed in all other groups $(\mathrm{p}<0.05)$, while the last sample showed values similar to those observed in animals in human care and in the wild.

The median number of HSP70 mRNA transcripts was highest in porpoises in human care (0.655 norm. copies), followed by free-ranging animals (0.601 norm. copies). The lowest number of HSP70 transcripts was found in animals in rehabilitation (0.285 norm. copies).

\section{HP}

HP expression levels were significantly higher in male porpoises in all groups $(p=0.008$; Figure $4 \mathrm{~b})$. The median number of HP mRNA transcripts was highest in porpoises in human care (5.37 norm. copies), followed by free-ranging animals (4.66 norm. copies). The lowest number of HP mRNA transcripts was found in porpoises in rehabilitation (4.28 norm. copies).

\section{CRP}

Porpoises in rehabilitation showed highest levels of CRP expression ( $\mathrm{p}=0.006)$, but no differences were found between porpoises in human care and free-ranging porpoises or between porpoises in human care and in rehabilitation $(\mathrm{p}>0.2)$.

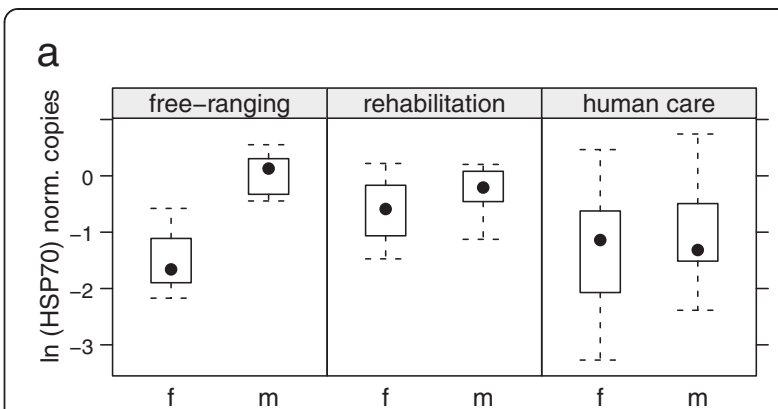

b

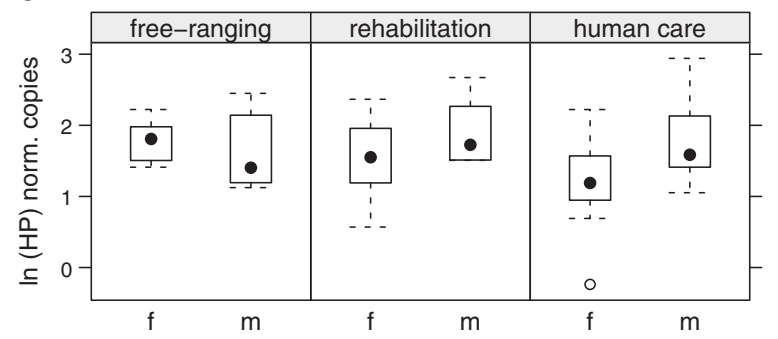

Figure 4 Normalised number of copies measured in male and female free-ranging, rehabilitated and permanently kept porpoises of a): HSP70 mRNA transcripts and b): Hp mRNA transcripts.

\section{Cytokines}

\section{Interleukin 10}

IL-10 mRNA expression levels were significantly higher in free-ranging porpoises than in animals in human care $(\mathrm{p}=0.0196$; Figure 5$)$. The median number of IL-10 mRNA transcripts was lowest in porpoises in human care $(0.006$ norm. copies), followed by individuals in rehabilitation (0.0095 norm. copies). The highest number of IL-10 mRNA transcripts was found in free-ranging animals (0.011 norm. copies).

When separating the individuals from rehabilitation, both first values measured in rehabilitation (median: 0.011 norm. copies) and the values of free-ranging animals were significantly different from individuals in human care $(\mathrm{p}<0.05)$, while the last sample showed values (median: 0.006 norm. copies) similar to those measured in individuals in human care.

Table 3 Median and first to third quartile of all mRNA expression levels for free-ranging porpoises, porpoises in rehabilitation and in human care (normalised number of copies)

\begin{tabular}{|c|c|c|c|c|c|c|c|c|c|}
\hline & \multicolumn{3}{|c|}{ Free-ranging } & \multicolumn{3}{|c|}{ Rehabilitation } & \multicolumn{3}{|c|}{ Human care } \\
\hline & $n$ & median & 1. - 3. quartile & $n$ & median & 1. - 3. quartile & $n$ & median & 1. - 3. quartile \\
\hline HSP70 & 14 & 0.60 & $0.19-1.05$ & 33 & 0.29 & $0.19-0.54$ & 19 & 0.66 & $0.37-0.95$ \\
\hline $\mathrm{HP}$ & 15 & 4.66 & $3.9-7.76$ & 33 & 4.28 & $3.4-6.39$ & 19 & 5.37 & $3.9-7.2$ \\
\hline TNFa & 15 & 0.17 & $0.14-0.47$ & 32 & 0.396 & $0.19-0.83$ & 18 & 0.42 & $0.27-0.53$ \\
\hline CRP & 13 & 0.005 & $0.001-0.013$ & 26 & 0.026 & $0.005-0.049$ & 19 & 0.01 & $0.003-0.011$ \\
\hline IL-10 & 15 & 0.011 & $0.01-0.022$ & 26 & 0.0095 & $0.005-0.012$ & 13 & 0.006 & $0.003-0.009$ \\
\hline
\end{tabular}

$\mathrm{n}=$ number of samples. 


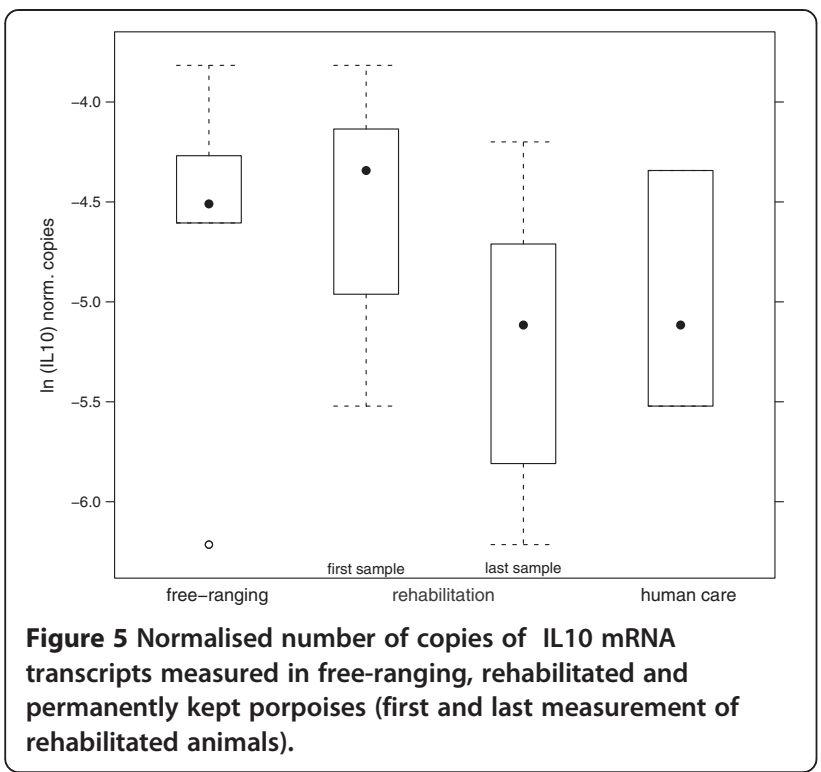

\section{TNFa}

TNF $\alpha$ showed no significant differences between groups $(\mathrm{p}=0.14)$ and sexes $(\mathrm{p}>0.4)$. However, TNF $\alpha$ was correlated with CRP (rho $=0.81, \mathrm{p}<0.001$ ).

\section{Correlations between hormones and molecular biomarkers}

Correlations were found in stress hormone and mRNA expression levels: IL-10 (rho $=0.44, \mathrm{p}=0.0509)$ and haptoglobin ( $\mathrm{rho}=0.59, \mathrm{p}=0.0039$ ) showed significant correlations with normetanephrine. Haptoglobin correlated with metanephrine ( $\mathrm{rho}=0.64, \mathrm{p}=0.001$ ). There was a positive correlation between IL-10 and cortisol (rho $=0.46, \mathrm{p}=0.004)$.

\section{Discussion}

Information about hormone status in harbour porpoises is still scarce compared to other marine mammals [11]. Comprehensive studies regarding levels of a broad spectrum of hormones in harbour porpoises have started recently and first results were published in a pilot study [9]. Most of the research performed has focused on thyroid hormones and cortisol [12,16,42]. Although cortisol is one of the most important hormones in stress reaction, its use as a single biomarker of stress is problematic because it does not permit a full assessment of stress situations [22,43]. The present study provides insights in changes in hormone levels as well as in expression levels of immunorelevant molecular biomarkers of harbour porpoises in different stress situations. Captureinduced stress and animal health may be reflected by different markers and may not be related. But the complex mechanisms of the immune and stress response may cause parameters to interact and influence each other, like IL-10 and cortisol in this study.

\section{Catecholamines}

Only little is known about the function of catecholamines as neurotransmitters and hormones in marine mammals. They are associated with an acute fight-orflight response and their secretion increases rapidly in response to a stressor $[11,19]$. Median levels of the catecholamines adrenaline, noradrenaline and dopamine estimated in this study were higher in free-ranging harbour porpoises compared to porpoises in human care. Those differences were significant for adrenaline and noradrenaline, most likely caused by the stressful situation for the free-ranging porpoises during capture and handling [9]. The lower median levels in harbour porpoises in human care and at the end of rehabilitation might be explained by an adaptation of those animals to the repeated procedure of sampling. A comparison of catecholamine levels of free-ranging porpoises measured in this study with levels measured by [9] resulted in values three times higher for adrenaline and dopamine and even eight times higher for noradrenaline in the present study. Captive belugas (Delphinapterus leucas) exposed to playbacks of high amplitude noise from oil drilling rigs showed little or no discernible effect on adrenaline and noradrenaline concentrations [44], whereas a significant increase in adrenaline, noradrenaline and dopamine concentrations in captive belugas exposed to sound was observed by other researchers [10]. Although no firm conclusions can be drawn due to limited sample size, the findings correspond with those of other authors [10,11] and indicate that catecholamines can be used as markers of stress in harbour porpoises.

\section{Cortisol and adrenocorticotropic hormone}

Glucocorticoids such as cortisol have many physiological functions in metabolism and the nervous and cardiovascular systems. They have an immunosuppressive and anti-inflammatory effect. The release of ACTH is mediated by corticotrophin-releasing hormone ( $\mathrm{CRH})$. Under stress, ACTH is released in a pulsatile fashion [45] and is responsible for the stimulation of cortisol secretion in the adrenal cortex. The median levels of ACTH and cortisol for free-ranging porpoises estimated in this study were significantly higher than those for porpoises in rehabilitation and in human care. This was observed earlier in a study in which free-ranging porpoises showed ACTH concentrations five times higher than individuals in human care [9]. Animals in human care taken out of the water for blood sampling were shown to have higher levels of cortisol than animals presenting their fluke for a voluntary blood sample [16]. The cortisol levels of free-ranging porpoises in the present study were similar to those measured in porpoises during tagging [12]. Nevertheless, it has to be taken into account that the range of measured cortisol levels was highly variable in 
all investigated groups, indicating an individual response to the same treatments. The fact that the cortisol levels estimated at the beginning of rehabilitation were close to the range of the free-ranging animals and the levels at the end of rehabilitation were similar to the range in animals in human care indicates a habituation of the animals to the handling procedure. Interestingly, the cortisol levels in the present study were close to the levels measured in blood samples voluntarily given by porpoises in human care [16].

\section{Metanephrine and normetanephrine}

These parameters, as methylation products of adrenaline and noradrenaline, were used as more stable equivalents, but a tendency or change in values between the groups or a correlation between metanephrine and adrenaline as well as between normetanephrine and noradrenaline values did not appear, probably because sample sizes for estimating metanephrine and normetanephrine were much smaller than for adrenaline and noradrenaline. Multiple sampling in one porpoise in rehabilitation produced correlating adrenaline/metanephrine and noradrenline/nor-metanephrine gradients. This may be due to the longer half-life of catechalomines in marine mammal metabolism [10,11]. In free-ranging animals multiple samples were taken within several hours when degradation products had not yet been produced, while samples from porpoises in rehabilitation were taken over a period of several days. The correlations between metanephrine and normetanephrine and acutephase protein biomarkers (HP, HSP70) indicate that these markers are expressed in stress responses.

\section{APP}

\section{HSP70}

The synthesis of HSP70 can be induced by heat, lack of glucose, hyperosmolarity, hypoxia or ischemia [46]. As cell mediator HSP70 transfers unspecific stress information to the innate and adaptive immune system [47]. Upregulation of HSP70 constrains secretion of TNF $\alpha$ [48]. Expression levels of HSP70 in this study were highest in porpoises in human care, followed by freeranging animals. The lowest number of HSP70 transcripts was found in porpoises in rehabilitation, whereas TNF $\alpha$ and CRP were highest in rehabilitation. Values of first samples taken from animals in rehabilitation were significantly lower than in porpoises from the other groups $(\mathrm{p}<$ 0.05). Female porpoises showed significantly lower HSP70 expression levels than males. It has been reported that male rats show higher expressions of heat-shock protein genes (e.g. HSP70) suggesting that cellular stress is elevated in males [49]. Other studies on mammals have shown that HSP70 expression is induced by exercise possibly correlated to the findings in this study where diseased animals in rehabilitation showed lowest levels and that this effect is attenuated by female hormones [50]. Sex-related differences in APP expression levels show the biological differences between sexes and indicate the wide physiological impact of hormones on the metabolism.

\section{HP}

Highest ranges were measured in porpoises in human care, probably induced by elevated TNF $\alpha$ levels [51].

An increase in HP concentrations can be caused by inflammation and infectious diseases and is associated with physical, psychological or environmental stress. HP values varied strongly in stable Steller Sea lion (Eumetopias jubatus) and harbour seal (Phoca vitulina) populations in the region of Alaska when compared to other populations undergoing a strong population decrease over several years [14]. High HP expression was described for harbour porpoises correlating with increased leukocytes [33]. However, the same was not observed in the free-ranging porpoises of the present study.

Female porpoises showed significantly lower HP expression levels than males. This was also observed for HSP70 and could reflect hormone attenuated or sexrelated differences in APP expression.

\section{CRP}

The correlation found between CRP and TNF $\alpha$ probably shows that both markers interact physiologically and that animals in rehabilitation, with highest values, were diseased.

\section{Cytokines}

\section{IL-10}

Significantly higher IL-10 values $(\mathrm{p}=0.0196)$ were found in free-ranging porpoises than in those in human care. Elevated IL-10 levels may indicate a continuous stimulation of the immune system due to infectious agents [52] in porpoises from the wild. IL-10 is an antiinflammatory cytokine and inhibits several immune responses, e.g. the production of pro-inflammatory cytokines such as TNF $\alpha[53,54]$. The correlation between IL-10 and cortisol observed in this study may indicate higher stress levels and more exposure to infectious disease in free-ranging porpoises.

\section{TNFa}

TNF $\alpha$ belongs to the early immune response of proinflammatory cytokines, and induces APP. The correlation found between TNF $\alpha$ and CRP in this study probably reflects this mechanism and also shows that both markers may be expressed as a sign of disease, as porpoises in rehabilitation showed highest values.

Indication for induction of APPs by TNF $\alpha$ was also found in both HP and HSP70 that showed high values in 
porpoises in human care. Although no significant differences were found between groups, a clear trend for lowest numbers of TNF $\alpha$ transcripts in free-ranging porpoises and for highest numbers in porpoises in human care was apparent. Glucocorticoids and catecholamines are supposed to constrain secretion of TNF $\alpha$ [55]. Low levels of $\mathrm{TNF} \alpha$ in free-ranging porpoises may be caused by constraint due to stress hormones, but as the endocrine and immune systems are complex systems this is difficult to determine.

\section{Conclusions}

In conclusion, profiles of stress hormones can be a useful tool for the determination of stress in harbour porpoises. Stress hormone levels are significantly higher in free-ranging porpoises compared to animals in human care as well as compared to animals in rehabilitation when splitting those measured values in first and last sample during the rehabilitation period. This decrease of hormone levels due to habituation to human handling demonstrates the importance of investigations on animals during the rehabilitation process.

Hormone levels of free-ranging harbour porpoises and animals at the beginning of rehabilitation can be seen as base values for stressed porpoises, levels of porpoises in human care and at the end of rehabilitation as base values for less stressed, habituated porpoises, possibly equalling the baseline values of wild healthy porpoises. Nevertheless, the variation in measured values, especially in free-ranging porpoises, has to be taken into account. Diverse factors might explain this variation, e.g. the natural variation among the wild species, different age categories or unknown variation in life history and environmental conditions. The investigation of the mRNA expression of the immunorelevant biomarkers reflects the development of the immune status over time and therefore serves as a sensible indicator for the effect of stress on the early immune response. The positive correlations observed in this study (e.g. IL-10 and cortisol) demonstrate the dynamic interaction between immune response and stress response. Due to the complexity of the immune and endocrine systems, further investigations on harbour porpoises in permanent or temporary human care under controlled and repeated conditions are needed to unravel the remaining uncertainties.

\footnotetext{
Abbreviations

$\mathrm{CRH}$ : Corticotropin-releasing hormone; $\mathrm{ACTH}$ : Adrenocorticotropic hormone; mRNA: Messenger-Ribonucleic acid; HSP70: Heat shock protein 70; IL10: Interleukin10; TNFa: Tumor necrosis factor a; n: number;

EDTA: Ethylenediaminetetraacetic acid; C: Celsius;

EGTA: Ethyleneglycoltetraacetic acid; HPLC: High-performance liquid chromatography; ECLIA: Electrochemiluminescent immunoassay; UK: United Kingdom; GAPDH: Glyceraldehyde 3-phosphate dehydrogenase; APP: Acutephase proteins; CRP: C-reactive protein; YWHAZ: 14-3-3 proteinzeta/delta; HP: Haptoglobin; RT-PCR: Real-time polymerase chain reaction; PCR: Polymerase chain reaction; LMM: Linear mixed models; Porpoise
}

ID: Identification number of individual porpoises; ID: Identification; AIC: Akaikes Information Criterion; ALP: Alkaline phosphatase; GPT: Glutamic pyruvic transaminase; Fig: Figure; Tab: Table; DK: Denmark; NL: The Netherlands.

\section{Competing interests}

The authors declare that they have no competing interests.

\section{Authors' contributions}

$J \mathrm{D}, \mathrm{EE}, \mathrm{JK}, \mathrm{CVN}, \mathrm{SM}$ and JT conducted sampling and preparation of samples. $\mathrm{SM}, \mathrm{HS}, J \mathrm{D}, \mathrm{US}$ and $\mathrm{KL}$ conducted analyses. KR conducted the statistical analyses. SM, KL, KR, JD and US drafted the manuscript and the other authors contributed to the manuscript. All authors read and approved the final manuscript.

\section{Acknowledgements}

This study was partly funded by the Federal Agency for Nature Conservation under the contract Z1.2-5330/2010/14 and the BfN-Cluster 7 "Effects of underwater noise on marine vertebrates". The field work was approved and carried out under permissions from the Danish Nature Agency (NST-344600016) and Danish Ministry of Justice (2010-561-1801). We thank all of the volunteers and employees at the SOS Dolfijn, Dolfinarium Harderwijk and the Fjord \& Baelt for handling and caring for the harbour porpoises. We would like to thank the pound net fishermen and all individuals who assisted with the field and laboratory work.

\section{Author details}

${ }^{1}$ Institute for Terrestrial and Aquatic Wildlife Research, University of Veterinary Medicine Hannover, Foundation, Büsum 25761, Germany. ${ }^{2}$ Institute for Coastal Research, Helmholtz-Zentrum Geesthacht, Geesthacht 21502, Germany. ${ }^{3}$ Veterinary Clinic, Reinsbüttel 25764, Germany. ${ }^{4}$ Departement of Bioscience, Aarhus University, Frederiksborgvej 399, 4000, Roskilde, Denmark. ${ }^{5}$ Dolfinarium Harderwijk, Strandboulevard Oost 1, Harderwijk, AB 3841, The Netherlands. ${ }^{6}$ Fjord and Belt, Margrethes Plads 1, Kerteminde 5300, Denmark. ${ }^{7}$ SOS Dolfijn, Strandboulevard Oost 1, Harderwijk, AB 3841, The Netherlands.

Received: 22 March 2013 Accepted: 9 July 2013

Published: 17 July 2013

\section{References}

1. Siebert U, Gilles A, Lucke K, Ludwig M, Benke H, Kock KH, Scheidat M: A decade of harbour porpoise occurrence in German waters - analyses of aerial surveys, incidental sightings and strandings. J Sea Res 2006, 56(1):65-80.

2. Scheidat M, Gilles A, Kock KH, Siebert U: Harbour porpoise Phocoena phocoena abundance in the southwestern Baltic Sea. Endang Species Res 2008, 5:215-223.

3. Gilles A, Scheidat M, Siebert U: Seasonal distribution of harbour porpoises and possible interference of offshore wind farms in the German North Sea. Mar Ecol Prog Ser 2009, 383:295-307.

4. Richardson WJ, Greene CR, Malme C, Thomson D: Marine mammals and noise. New York: Academic Press; 1995:567.

5. Jepson PD, Baker JR, Kuiken T, Simpson VR, Kennedy S, Bennett PM: Pulmonary pathology of harbour porpoises stranded in England and Wales between 1990 and 1996. Vet Rec 2000, 146:721-728.

6. Siebert U, Joiris C, Holsbeek L, Benke H, Failing K, Frese K, Petzinger E: Potential relation between mercury concentrations and necropsy findings in cetaceans from German waters of the North and Baltic Seas. Mar Pollut Bull 1999, 38:285-295.

7. Vinther M, Larsen F: Updated estimates of harbour porpoise (Phocoena phocoena) bycatch in the Danish North Sea bottom-set gillnet fishery. J Cetac Res Manage 2004, 6:19-24.

8. Lucke K, Siebert U, Lepper P, Blanchet MA: Temporary shift in masked hearing thresholds in a harbor porpoise (Phocoena phocoena) after exposure to seismic airgun stimuli. J Acoust Soc Am 2009, 125:4060-4070.

9. Siebert U, Pozniak B, Anderson Hansen K, Nordstrom G, Teilmann J, van Elk N, Vossen A, Dietz R: Investigations of thyroid and stress hormones in free-Ranging and captive harbor porpoises (Phocoena phocoena): a pilot study. Aquat Mamm 2011, 37(4):443-453.

10. Romano TA, Keogh MJ, Kelly C, Feng P, Berk L, Schlundt CE, Carder DA, Finneran JJ: Anthropogenic sound and marine mammal health: measures 
of the nervous and immune systems before and after intense sound exposure. Can J Fish Aquat Sci 2004, 61(7):1124-1134.

11. St. Aubin DJ, Dierauf LA: In Handbook of marine mammal medicine. Edited by Dierauf LA, Gulland FMD. Boca Raton, FL: CRC Press; 2001:253-270.

12. Eskesen IG, Teilmann J, Geertsen BM, Desportes G, Riget F, Dietz R, Larsen F, Siebert U: Stress level in wild harbour porpoises (Phocoena phocoena) during satellite tagging measured by respiration, heart rate and cortisol. J Mar Biol Assoc UK 2009, 89(5):885-892.

13. St. Aubin DJ, Ridgway SH, Wells RS, Rhinehart H: Dolphin thyroid and adrenal hormones: circulating levels in wild and semi domesticated Tursiops truncatus, and influence of sex, age, and season. Mar Mamm Sci 1996, 12(1):1-13.

14. Zenteno-Savin T, Castellini MA, Rea LD, Fadely BS: Plasma haptoglobin levels in threatened Alaskan pinniped populations. J Wildl Dis 1997, 33(1):64-71.

15. Ortiz RM, Worthy AJ: Effects of capture on adrenal steroid and vasopressin concentrations in free-ranging bottlenose dolphins (Tursiops truncatus). Comp BiochemPhysiol Part A 2000, 125:317-324.

16. Desportes $G$, Buholzer L: Anderson Hansen K, Blanchet M, Acquarone M, Shepard G, Brando S, Vossen A, Siebert U: Decrease stress; train your animals: the effect of handling methods on cortisol levels in harbour porpoises (Phocoena phocoena) under human care. Aquat Mamm 2007, 33:286-292.

17. Wright RJ, Cohen RT, Cohen S: The impact of stress on the development and expression of atopy. Curr Opin Allergy Clin Immunol 2005, 5:23-29.

18. Das K, Vossen A, Tolley K, Vikingsson G, Thron K, Mueller G, Baumgaertner W, Siebert U: Interfollicular fibrosis in the thyroid of the harbour porpoise: an endocrine disruption? Arch Environ Contam Toxicol 2006, 51:720-729.

19. Henry JP: Biological basis of the stress response. Integr Physiol Behav Sci 1992, 27(1):66-83.

20. Fair PA, Becker PR: Review of stress in marine mammals. J Aquat Ecosyst Stress Recover 2000, 7:335-354.

21. Feldman EC, Nelson WN: Canine and Feline Endocrinology and Reproduction. 3rd edition. Philadelphia, PA: Elsevier; 2004

22. Moberg GP: Problems of defining stress and distress in animals. J Am Vet Med Assoc 1987, 191:1207-1211.

23. Kawamura N, Kim Y, Asukai N: Suppression of Cellular Immunity in Men With a Past History of Posttraumatic Stress Disorder. Am J Psychiatry 2001, 158(3):484-486.

24. Kostro K, Wojcicka-Lorenowicz K, Glinski Z, Krakowski L, Wrona Z: Acute phase proteins as ligands of cells of the immune system. Med Weter 2002, 58:929-933.

25. Murata H, Shimada N, Yoshioka M: Current research on acute phase proteins in veterinary diagnosis: an overview. Vet J 2004, 168:28-40.

26. Petersen $\mathrm{HH}$, Nielsen JP, Heegaard PMH: Application of acute phase protein measurements in veterinary clinical chemistry. Vet Res 2004, 35:163-187.

27. Young RA: Stress proteins and immunology. Annu Rev Immunol 1990, 8:401-420.

28. Njemini R, Abeele MV, Demanet C, Lambert M, Vandebosch S, Mets T: Agerelated decrease in the inducibility of heat-shock protein 70 in human peripheral blood mononuclear cells. J Clin Immunol 2002, 22:195-205.

29. Beineke A, Siebert U, van Elk N, Baumgärtner W: Development of a lymphocyte-transformation-assay for peripheral blood lymphocytes of the harbor porpoise and detection of cytokines using the reversetranscription polymerase chain reaction. Vet Immunol Immunopathol 2004 98:59-68.

30. Beineke A, Siebert U, Müller G, Baumgärtner W: Increased blood interleukin-10 mRNA levels in diseased free-ranging harbor porpoises (Phocoena phocoena). Vet Immunol Immunopathol 2006, 115:100-106.

31. Denis F, Archambault D: Molecular cloning and characterization of beluga whale (Delphinapterus leucas) interleukin-1beta and tumor necrosis factor-alpha. Can J Vet Res 2001, 65(4):233-240.

32. Fonfara S, Siebert U, Prange A, Colijn F: The impact of stress on cytokine and haptoglobin mRNA expression in blood samples from harbour porpoises (Phocoena phocoena). J Mar Biol Assoc UK 2007, 87:305-311.

33. Fonfara $S$, Siebert U, Prange A: Cytokines and acute phase proteins as markers for infections in harbour porpoises (Phocoena phocoena). Mar Mamm Sci 2007, 23(4):931-942.

34. Fonfara S, Kakuschke A, Rosenberger T, Siebert U, Prange A: Cytokine and acute phase protein expression in blood samples of harbour seal pups. Mar Biol 2008, 155:337-345.
35. Funke C, King DP, Brotheridge RM, Adelung D, Stott JL: Harbor seal (Phoca vitulina) $\mathrm{C}$-reactive protein (C-RP): purification, characterization of specific monoclonal antibodies and development of an immuno-assay to measure serum C-RP concentrations. Vet Immunol Immunopathol 2003, 59(1-2):151-162.

36. Inoue Y, Itou T, Jimbo T, Syouji Y, Ueda K, Sakai T: Molecular cloning and functional expression of bottle-nosed dolphin (Tursiops truncatus) interleukin1 receptor antagonist. Vet Immunol Immunopathol 2001, 78:131-141.

37. Ness TL, Bradley WG, Reynolds JE, Roess WB: Isolation and expression of the interleukin-2 gene from the killer whale, Orcinus orca. Mar Mamm Sci 1998, 14:531-543.

38. Seibel H: Influence of a canine distemper virus infection on the expression of cytokines in phocine lymphocytes. Inaugural dissertation, University of Veterinary Medicine Hannover, Foundation. Giessen, Germany: Department of Pathology; DVG Service GmbH; 2009. pp. 17 (in German). ISBN 978-3 $-941703-45-2$.

39. Vandesompele J, De Preter K, Pattyn F, Poppe B, Van Roy N, De Paepe A Speleman F: Accurate normalization of real-time quantitative RT-PCR data by geometric averaging of multiple internal control genes. Genome Biol 2002, 3:1-12.

40. R Core Team: R: A language and environment for statistical computing. Vienna, Austria: R Foundation for Statistical Computing; 2012. URL http:// www.R-project.org/. ISBN 3-900051-07-0.

41. Pinheiro J, Bates D, DebRoy S, Sarkar D, he R Development Core Team: nlme: Linear and Nonlinear Mixed Effects Models. R package version 3. 2012:1-104.

42. Koopman HN, Westgate AJ, Read AJ: Hematology values of wild harbour porpoises (Phocoena phocoena) from the Bay of Fundy, Canada. Mar Mamm Sci 1999, 15:52-64.

43. Rushen J: Some problems with the physiological concept of stress. Aust Vet J 1986, 63:359-361.

44. Thomas JA, Kastelein RA, Awbrey FT: Behaviour and blood catecholamines of captive beluga whales during playbacks of noise from an oil drilling platform. Zoo Biol 1990, 9:393-402.

45. Mimoto T, Mishioka T, Asaba K, Takao T, Harashimoto K: Effects of adrenomedullin on adrenocorticotropic hormone $(\mathrm{ACTH})$ release in pituitary cell cultures and on ACTH and oxytocin responses to shaker stress in conscious rat. Brain Res 2001, 922(2):261-266.

46. Deane EE, Kelly SP, Lo CK, Woo NY: Effects of GH, prolactin and cortisol on hepatic heat shock protein 70 expression in a marine teleost Sparus sarba. J Endocrinol 1999, 161:413-421

47. Chen T, Cao X: Stress for maintaining memory: HSP70 as a mobile messenger for innate and adaptive immunity. Eur J Immunol 2010, 40(6):1541-1544.

48. Meng X, Alden H: The interaction between HSP70 and TNF-[alpha] expression: a novel mechanism for protection of the myocardium against post-injury depression. Shock 2002, 17(5):345-353.

49. Klein SL, Cernetich A, Hilmer S, Hoffmann EP, Scott AL, Glass GE: Differential expression of immunoregulatory genes in male and female Norway rats following infection with Seoul virus. J Med Virol 2004, 74(1):180-190.

50. Paros Z, Dipchand ES, Noble EG: Estrogen attenuates postexercise HSP70 expression in skeletal muscle. Am J Physiol Cell Physiol 2002, 282(2):245-251.

51. Berkova N, Gilbert C, Goupil S, Yan J, Korobko V, Naccache PH: TNF-induced haptoglobin release from human neutrophils: pivotal role of the TNF p55 receptor. J Immunol 1999, 162(10):6226-6232.

52. Beineke A, Siebert U, Müller G, Baumgärtner W: Increased blood interleukin-10 mRNA levels in diseased free-ranging harbor porpoises (Phocoena phocoena). Vet Immunol Immunopathol 2007, 115:100-106.

53. Fiorentiono D, Bond M, Mosmann TR: Two types of mouse Thelper cell. IV. Th2 clones secrete a factor that inhibits cytokine production by Th1 clones. J Exp Med 1989, 170:2081-2095.

54. De Waal Malefyt R, Abrams J, Bennet B, Figdor C, De Vries JE: Interleukin 10 (IL-10) inhibits cytokine synthesis by human monocytes: an autoregulatory role of IL-10 produced by monocytes. J Exp Med 1991, 174:1209-1220.

55. Calcagni E, Elenkov I: Stress System Activity, Innate and T Helper Cytokines, and Susceptibility to Immune-Related Diseases. Ann NY Acad Sci 2006, 1069:62-76.

doi:10.1186/1746-6148-9-145

Cite this article as: Müller et al:: Evaluation of immune and stress status in harbour porpoises (Phocoena phocoena): can hormones and mRNA expression levels serve as indicators to assess stress?. BMC Veterinary Research 2013 9:145. 